\title{
A reporting guide for implementation science articles
}

Correspondence: ccdr-rmtc@phac-aspc.gc.ca

Suggested citation: A reporting guide for implementation science articles. Can Comm Dis Rep 2016;42:175-6. https://doi.org/10.14745/ccdr.v42i09a01

Many health and public health practitioners are interested in "what's new" - how evidence can be applied to practice and what works. Implementation science has been described as the scientific study of methods to promote the uptake of research findings into routine healthcare in clinical, organizational or policy contexts (1). In the Canada Communicable Disease Report (CCDR), this can include any process, procedure, policy or program designed to decrease the human impact of an infectious disease.

There is often a gap between the positive findings of an experimental study and outcomes in practice. This is in part because effective implementation is difficult. It requires significant knowledge, skills and effort to assess, plan, adapt, deliver, monitor and evaluate an intervention. Implementation science aims to understand and decrease the gap between evidence and practice. Excellent manuals have been developed, such as one by the RAND Corporation (2) and a variety of theoretical models have been proposed and are being tested $(3,4)$. These have revealed that multiple factors are at play. For example, a systematic review identified that evidence-based clinical practice guidelines were almost three times more likely to be adopted if they were supported by a facilitator who used strategies such as audit and feedback, as well as interactive consensus building and goal setting (5). Clearly, implementation is both an art and a science.

Because there has been little guidance available to date for reporting implementation science articles, the CCDR has developed a 20 -item checklist based on the literature and best practice in scientific communications. This checklist identifies the need to describe what is being implemented and why, who is being targeted and where, how the implementation was done, what the outcomes were, what lessons were learned and potential next steps (Table 1).

An implementation science paper is usually 1,500 to 2,000 words in length. As with all submissions, check CCDR's Information for authors, published at the beginning of a new volume in January of each year for general manuscript preparation and submission requirements (6).
Table 1: Checklist for implementation science papers

\begin{tabular}{|c|c|c|}
\hline Reporting item & No. & Description \\
\hline \multicolumn{3}{|l|}{ Title/Abstract } \\
\hline Title & 1 & $\begin{array}{l}\text { Compose a title that includes the } \\
\text { population, condition or primary issue } \\
\text { addressed in the study. }\end{array}$ \\
\hline Abstract & 2 & $\begin{array}{l}\text { Provide a } 200 \text { to } 250 \text {-word abstract using } \\
\text { the following sub-headings: Background, } \\
\text { Objective, Intervention, Outcomes and } \\
\text { Conclusion. }\end{array}$ \\
\hline \multicolumn{3}{|l|}{ Introduction } \\
\hline $\begin{array}{l}\text { Issue } \\
\text { identification }\end{array}$ & 3 & $\begin{array}{l}\text { Identify the topic of the study and why it } \\
\text { is important. }\end{array}$ \\
\hline $\begin{array}{l}\text { What is known to } \\
\text { date }\end{array}$ & 4 & $\begin{array}{l}\text { Provide a summary of the literature } \\
\text { relating to the topic and identify any } \\
\text { existing gaps. }\end{array}$ \\
\hline $\begin{array}{l}\text { Rationale for } \\
\text { study }\end{array}$ & 5 & $\begin{array}{l}\text { Identify the rationale for the } \\
\text { implementation study. }\end{array}$ \\
\hline Objective & 6 & State the objective of the intervention. \\
\hline \multicolumn{3}{|l|}{ Intervention } \\
\hline $\begin{array}{l}\text { Setting/ } \\
\text { participants }\end{array}$ & 7 & $\begin{array}{l}\text { Describe the setting and population used } \\
\text { for the implementation study, and the } \\
\text { rationale for both. }\end{array}$ \\
\hline $\begin{array}{l}\text { Ethics review if } \\
\text { indicated }\end{array}$ & 8 & $\begin{array}{l}\text { For studies involving human participants, } \\
\text { include a statement detailing ethical } \\
\text { approval and consent. }\end{array}$ \\
\hline Intervention & 9 & $\begin{array}{l}\text { Describe the intervention and how it } \\
\text { was carried out. If applicable, state who } \\
\text { offered the intervention, how participants } \\
\text { were enlisted, what efforts were made } \\
\text { to adapt the intervention to local needs, } \\
\text { enabling factors and any training given. }\end{array}$ \\
\hline $\begin{array}{l}\text { Outcome } \\
\text { measures }\end{array}$ & 10 & $\begin{array}{l}\text { Describe how the intervention was } \\
\text { assessed. This may include descriptive } \\
\text { statistics about the participants (or } \\
\text { target population) as well as primary } \\
\text { and secondary outcome measures. } \\
\text { If appropriate, describe the analyses } \\
\text { conducted to examine sub-groups, } \\
\text { interactions and confounding factors. }\end{array}$ \\
\hline \multicolumn{3}{|l|}{ Outcomes } \\
\hline $\begin{array}{l}\text { Setting/ } \\
\text { participants }\end{array}$ & 11 & $\begin{array}{l}\text { Present the findings in enough detail to } \\
\text { give a sense of the participants or target } \\
\text { population, time and place. }\end{array}$ \\
\hline Primary outcomes & 12 & Present the primary outcome measure(s). \\
\hline
\end{tabular}




\begin{tabular}{|l|c|l|}
\hline $\begin{array}{l}\text { Secondary } \\
\text { outcomes }\end{array}$ & 13 & $\begin{array}{l}\text { Provide any secondary outcome measures, } \\
\text { sub-group analysis, interactions or } \\
\text { confounding factors if applicable. }\end{array}$ \\
\hline $\begin{array}{l}\text { Intervention } \\
\text { experience }\end{array}$ & 14 & $\begin{array}{l}\text { Describe any insights that arose as a result } \\
\text { of implementing the intervention. }\end{array}$ \\
\hline Discussion & 15 & $\begin{array}{l}\text { Summarize and interpret the key findings } \\
\text { of the intervention and its implementation. }\end{array}$ \\
\hline $\begin{array}{l}\text { Summary of key } \\
\text { findings }\end{array}$ & 16 & $\begin{array}{l}\text { Compare the results of the intervention } \\
\text { with previous findings (such as how the } \\
\text { intervention was implemented in different } \\
\text { populations or settings). }\end{array}$ \\
\hline $\begin{array}{l}\text { Comparisons } \\
\text { popthe }\end{array}$ & 17 & $\begin{array}{l}\text { Identify the strengths and limitations of } \\
\text { the intervention and its implementation. }\end{array}$ \\
\hline $\begin{array}{l}\text { Strengths and } \\
\text { limitations }\end{array}$ & 18 & $\begin{array}{l}\text { Consider implications, next steps or } \\
\text { further areas of inquiry (such as a more } \\
\text { in-depth evaluation, assessment in other } \\
\text { contexts, potential for scale-up and } \\
\text { sustainability). }\end{array}$ \\
\hline $\begin{array}{l}\text { Implications and } \\
\text { next steps }\end{array}$ & 19 & $\begin{array}{l}\text { Ensure the conclusion integrates the key } \\
\text { findings and addresses the objective of } \\
\text { the study. }\end{array}$ \\
\hline $\begin{array}{l}\text { Tables or figures } \\
\text { findings }\end{array}$ & $\begin{array}{l}\text { When appropriate, include an illustrative } \\
\text { diagram or table summarizing key points. }\end{array}$ \\
\hline
\end{tabular}

\section{References}

1. BioMed Central. Implementation Science Journal. London: BioMed Central; 2015. http://www.implementationscience. $\mathrm{com} /$.

2. Wiseman $\mathrm{SH}$, Chinman $\mathrm{M}$, Ebener $\mathrm{PA}$, Hunter $\mathrm{SB}, \mathrm{Imm}$ $P$, Wandersman A. Getting to outcomes ${ }^{\mathrm{TM}}$ : 10 steps for achieving results-based accountability. Santa Monica, CA: RAND Corporation, 2007. http://www.rand.org/pubs/ technical_reports/TR101z2.html.

3. Harvey G, Kitson A. PARIHS revisited: from heuristic to integrated framework for the successful implementation of knowledge into practice. Implement Sci. 2015;11:33. doi:10.1186/s13012-016-0398-2.

4. Damschroder L, Aron D, Keith R, Kirsh S, Alexander J, Lowery J. Fostering implementation of health services research findings into practice: a consolidated framework for advancing implementation science. Implement Sci. 2009;4:50. doi: 10.1186/1748-5908-4-50.

5. Baskerville NB, Liddy C, Hogg W. Systematic review and meta-analysis of practice facilitation within primary care settings. Ann Fam Med. 2012;10:63-74. doi: 10.1370/ afm.1312.

6. Information for authors. Can Comm Dis Rep 2016;42:20-21. http://www.phac-aspc.gc.ca/publicat/ccdr-rmtc/16vol42/drrm42-1/ar-04-eng.php.

\section{CALL FOR PAPERS \\ Have you created a new and interesting program showing promising results?}

Tell us about your work and see it published in our Spring 2017 issue on Implementation Science.

\section{Submissions due November 10, 2016}

For manuscript guidance, please visit our Submit a Manuscript page online: phac-aspc.gc.ca/publicat/ccdr-rmtc/ 